\title{
Criteria for science in the courts
}

The US Supreme Court may produce new criteria for the admissibility of scientific evidence in the courts on the basis of a suit now being heard.

THE question of what constitutes valid scientific data, suitable for admission as evidence in court, has plagued judges for decades. Generally unschooled in the scientific method, judges have the legal duty of deciding what may or may not be presented to a jury. For years, US judges have relied on a standard, dating back to 1923 and too often honoured in the breach, defining admissible evidence as that which derives from methods of inquiry that are 'generally accepted' by the scientific community. Frequently, courts have interpreted that to mean 'published in the peer-reviewed literature'.

A more lenient standard, set out in legislation in 1975 , permits judges (at their discretion) to admit as evidence almost any opinion from an 'expert witness', defined as someone who is qualified "by knowledge, skill, experience, training or education" to speak to a given subject. Each standard is in some way deficient.

First, it is (or should be) well known that the peer review system is not infallible and, further, that the best journals openly acknowledge that editorial judgement on the importance of a paper and its estimated interest to readers play an important role in deciding which papers to publish and which to reject. And even this journal has rejected papers that subsequently proved to be of exceptional significance. Thus to bar from the courts data that have not appeared in a peer reviewed journal could be foolhardy. But it is also well known that the so-called expert witness in court may be a hired gun, willing to testify to anything for a fee, or a crackpot whose unsupportable ideas are masked by an advanced degree - often from a respectable university.

The issue of standards of evidence arises now because of a case just argued before the US Supreme Court over whether data do or do not support the allegation that a drug called Bendectin, once widely prescribed to prevent morning sickness in pregnant women, causes limb deformities in newborn babies. The manufacturer and the defendant in the case, Merrell Dow (now Marion Merrell Dow of Kansas City), has consistently won its case in some 200 lawsuits brought by parents who claim that Bendectin is a teratogen. The company can cite more than 25 published epidemiological studies indicating no correlation between Bendectin (which was taken by more than 30 million women worldwide) and limb deformities. (Nevertheless, because of the high cost of litigation, the company withdrew Bendectin from the market in 1983 , leaving women to rely on old-fashioned remedies to prevent what is, in some instances, a serious complication of pregnancy.)
The plaintiffs in earlier cases and that now before the Supreme Court, known as Daubert v. Merrell Dow Pharmaceuticals, have relied largely on the testimony of expert witnesses, some of whom have reached conclusions by analogy rather than direct experiment. Most of the time, the courts have ruled their testimony inadmissible. The issue has been cast in scientific circles and the press as a clash between 'good' science and what is scornfully described as 'junk' science because it fails to meet tests of scientific legitimacy. For instance, much of the case against Bendectin in Daubert rests on testimony by a Berkeley-trained epidemiologist, now affiliated with the California state health department, who claims that her "reanalysis" of the published epidemiological data shows a one in 1,000 incidence of limb deformities caused by Bendectin. She has not written up her data for publication.

What should the court do? Reflecting a befuddlement judges often express when dealing with science (and revealing again that science is not yet part of the mainstream of education) one of the justices said: "There are Harvard law professors on both sides of this case; I had hoped you could get together and lead us out of the wilderness." But it is not really a wilderness, as many of the 'friend of the court' briefs filed by scientific bodies suggest. One in particular (from the not-for-profit Carnegie Commission on Science, Technology and Government) offers a clear way out. The commission urges the justices to adopt a new standard for evidence that would require judges not to resolve scientific controversy but only to ask three pertinent questions in weighing admissibility of evidence: is the claim testable? Has it been tested? And is the methodology sound?

Courts should not exclude evidence just because it is not accepted wisdom; nor should they allow plaintiffs to be held liable on the basis of mere hypothesis or speculation. While it is true that speculation is an essential part of science, and true that new ideas may have a hard time gaining acceptance, it does not follow that untested science belongs in court. That would be bad public policy.

\section{An influential fellow}

The death two weeks ago of Lord Zuckerman will leave a sad gap in public life in Britain and elsewhere.

SOLly (as even his enemies called him) Zuckerman, more formally Lord Zuckerman, OM, was an iconoclast by 